\title{
The history of military cranioplasty
}

\author{
Christopher M. Bonfield, M.D., ${ }^{1}$ Anand R. Kumar, M.D., ${ }^{2}$ \\ and Peter C. Gerszten, M.D., M.P.H. ${ }^{1}$ \\ ${ }^{1}$ Department of Neurological Surgery, University of Pittsburgh Medical Center, Pittsburgh, Pennsylvania; \\ and ${ }^{2}$ Department of Plastic Surgery, The Johns Hopkins Hospital, Baltimore, Maryland
}

\begin{abstract}
There is evidence that the neurosurgical procedure of cranioplasty is as ancient as its better-known counterpart, trephination. With origins in pre-Incan Peru, cranioplasty remains an important reconstructive procedure for modern craniofacial surgery teams to master. Solutions to the often challenging problem of repairing skull defects continue to evolve to improve patient outcomes. Throughout recorded history, advances in cranioplasty have paralleled major military conflicts due to survivorship after trephination or decompressive craniectomy. Primitive skull coverings used in Peru were later replaced during the Middle Ages by grafts obtained in animals and humans. Improved survivorship secondary to advances in anesthesia and battlefield medicine during the Crimean War and the American Civil War allowed the use of tantalum and acrylic cranioplasty to evolve during World Wars I and II. In the modern era of the Iraq and Afghanistan conflicts, greater survivorship after cranial injury due to improvements in protective armor, medical evacuation, and early "far-forward" neurosurgical treatment have occurred. Consequently, the last decade has seen great advancement in cranial defect reconstruction, including custom-fabricated alloplast implants and the emergence of regenerative cranial treatments such as distraction osteogenesis, protected bone regeneration, and free tissue transfers. Comprehensive rehabilitation after neurotrauma has emerged as the new standard of care. (http://thejns.org/doi/abs/10.3171/2014.1.FOCUS13504)
\end{abstract}

\section{Key Words • cranioplasty • cranial defect • decompressive craniectomy • warfare-related trauma}

A LTHOUGH less well described and discussed than its complementary ancient neurosurgical procedure of trephination, reconstructive cranioplasty is no less important and equally intriguing. Throughout recorded history, numerous and diverse techniques have been developed to repair acquired defects of the human skull. New techniques and novel materials are continually being developed or improved to treat this complex problem properly. There is evidence of reconstructive cranioplasty treatments dating from the pre-Incan period in Peru, and later in the Middle East and Europe during the 16th-17th centuries. During the modern period, advances have paralleled the World Wars and, most recently, the conflicts in Iraq and Afghanistan. The nearly unbroken string of trauma, conflict, and war has been the primary source of innovation and advancements in this field of neurosurgery in the past, and remains so today. For this reason, this study explores the history of cranioplasty - following and connecting the ancient neurosurgical procedure to conflict and war, while highlighting major advances during each period of conflict.

Abbreviations used in this paper: WWI, WWII = World War I and II.

\section{Ancient History}

The earliest evidence of trephination documents preIncan surgeons in the area of the modern state of Peru performing the procedure as early as $3000 \mathrm{BCE} .^{25,26} \mathrm{Al}-$ though the exact indications and reasons for the procedure remain largely unknown, it has been estimated that $28 \%$ to $46 \%$ were undertaken for traumatic injuries, mainly as a result of battle. ${ }^{9,17,19}$ Lending evidence to a military connection, trephined skulls have been discovered more frequently in burial grounds of Incan fortresses than in those of coastal communities. Horrax ${ }^{13}$ postulated that the abundance of skull injuries in males suggested that trephination was performed in male soldiers injured in hand-to-hand combat. According to Lastres and Cabieses, ${ }^{17}$ Penfield reported that trephination was used in an attempt to evacuate subdural hematomas, whereas Horsley ${ }^{14}$ believed that the procedure was performed to elevate and remove depressed skull fractures.

There are far fewer, albeit no less convincing, more contemporary examples of cranioplasty in ancient Peru. Cushing $^{8}$ described skulls that were discovered with gold or silver plates covering the cranial defect, but he questioned the utility of such material. Other materials, such as coca, yerba mate, gourd, shells, coconut, calabash, and 


\section{M. Bonfield, A. R. Kumar, and P. C. Gerszten}

plants, were implanted, but all proved to be ineffective as well., ${ }^{2,69}$ Although the procedure may not have been entirely beneficial in all cases, cranioplasty appears to have its oldest evidence of practice in Peru. The link to military injuries also shares its origin here.

During the more classical era of history in Egypt, Greece, Rome, and Asia, little advancement was made in the area of cranioplasty. Trephination was reported, and cranial injuries in battle were described. However, the procedure appeared to fall out of favor, with importance being placed on application of the dressing over an open cranial wound rather than the restoration of a rigid cranial vault. ${ }^{11,26}$ Hippocrates described the practice of dressing the wounds with lint, with subsequent physicians and surgeons modifying his recommendations.

\section{6th-17th Centuries}

For the many centuries following the classical time period, there is little evidence of the practice of reconstructive cranioplasty. However, in the early 16th century, the procedure made its return in both the Middle East and in Europe. The first more modern recorded description of cranioplasty was discovered in the surgery textbook Alaim-I Cerrahin (Wonders of Surgeons), as detailed in Aciduman and Belen. ${ }^{1}$ Written in 1505 by Ibrahim bin Abdullah, the text outlines the repair of skull defects with xenografts. Living in a time of war in the Ottoman era, Ibrahim practiced as a military surgeon and became familiar with cranial wounds and their treatment. He guides other physicians: "If you encounter a cranial bone fracture presented either with a wide defect or with multiple smashed bones so that when bony parts are removed, a wide hole will occur, you are obliged to repair this defect by the following procedure; find a youngster of goat and slaughter it. If a goat is not obtainable you may use Karabash [Kangal dog].” These animals were readily obtainable for use by a military surgeon, because goats and Kangal dogs were used for food and protection by the Ottoman troops. Also, the goats were raised as livestock in the countryside, with the dogs shepherding them. Marching troops would be in close proximity to these animals, and the surgeon could have immediate access to this cranioplasty material if needed.

Around this same time, the Persian physician Baha al-Dowleh Razi wrote his book, the Khulasat al-Tajarib (Summary of Experiences). In this work he describes "a very skillful surgeon who used to cut damaged bones from the skull and cut the skull of a dog the same shape and place it on the damaged part" (see Shoja et al.). ${ }^{27}$ This surgeon has never been definitely identified; however, there is evidence that he was referring to Ibrahim.

In Europe, Fallopius was also developing a familiarity with cranioplasty. This was a result of his experience in the treatment of traumatic skull fractures. The fractured bone could be replaced if the dura mater was not violated, he advised. Otherwise, the bone should be removed and a gold plate inserted in its place (see Sanan and Haines). ${ }^{26}$ Prior to the discovery of Ibrahim's text, the first apparent report of a successful bone graft cranioplasty was published in 1668 by a Dutch surgeon, Job Janszoon van Meekeren. ${ }^{21}$ It recounts a sword injury to a Russian noble- man resulting in a cranial defect. The injury was repaired by a graft from a dog cranium, and allegedly the patient was threatened with excommunication from the church due to the animal tissue implanted in the man's head. ${ }^{12}$

\section{Modern War Era}

The next era of cranioplasty's evolution was pushed by further advances in battlefield medicine. In Boston, Massachusetts, on October 16, 1846, Dr. John Collins Warren performed the first surgery with the assistance of Dr. William Morton's ether inhalation, and the beginning of modern general anesthesia was celebrated. The advent of general anesthesia allowed for the creation of the modern military field hospitals, which made their first appearance in the Crimean War (1853-1886) and the American Civil War (1861-1865). ${ }^{4}$ As battlefield treatment improved, so did the number of soldiers who sustained injuries and survived. More survivors from the battlefield translated into more opportunities and need for cranioplasty procedures. However, these field hospitals were in their infancy during these conflicts. ${ }^{33}$ McLeod $^{20}$ reported a $73.7 \%$ mortality rate in 898 patients who suffered from head injury in the Crimean War. Similarly, the rate of mortality after head wounds sustained during the Civil War was 71.1\%.29 As Civil War surgeon Dr. Chisolm states so simply, "All wounds to the head are more or less serious." ${ }^{5}$

Trench warfare with hand-thrown grenades, which were extensively used in World War I (WWI), accounted for many head injuries and fragment injuries. However, as antiseptic and sterile techniques in surgery improved, mortality from such conflicts continued to decrease. The mortality rate resulting from head wounds in WWI decreased to $35 \%$ after Cushing ${ }^{7}$ introduced the techniques of surgical debridement and primary closure of open wounds. Along with the widespread adoption of these techniques, military surgeons reverted back to fashioning gold and silver plates for cranial defect repair. ${ }^{22}$

By the time of World War II (WWII), antibiotic use and further evolution of surgical treatments decreased the mortality rate to approximately $14 \% .^{30}$ Unlike during WWI, gold and silver were not used as cranioplasty material during WWII. ${ }^{32}$ Instead, other newer materials such as tantalum and acrylic resins were introduced to repair the high number of cranial defects left by this large-scale war. Fulcher ${ }^{10}$ first described the use of tantalum in $1943 .{ }^{23}$ It could be molded easily and did not elicit an inflammatory reaction in the surrounding tissues. However, the element was relatively expensive, and it led to the development of headaches in very hot and cold temperatures due to its heat and cold conduction properties. Furthermore, it was radiopaque and made subsequent diagnostic imaging difficult to interpret. Because of the drawbacks of tantalum, acrylic resins were introduced and widely used after WWII as well. Compounds such as methyl methacrylate were malleable and could cover large cranial defects like those produced by explosives and shrapnel. ${ }^{31}$

\section{Recent Conflicts}

The recent military conflicts in Iraq and Afghanistan 
have led to significant advances in cranioplasty techniques. Modern blast explosions create cavitary injuries that extend past the border of the surface wound, often creating both soft-tissue and cranial defects. ${ }^{28}$ However, advances in armor and immediate damage control with neurosurgery have resulted in more soldiers surviving such blast injuries. Currently, immediate treatment includes aggressive decompressive craniectomy, conservative brain debridement, and a watertight dural repair. ${ }^{24}$ Furthermore, whereas it used to take days for soldiers to get from the battlefield to neurosurgical care, the transport time has decreased to less than 1 hour in both Iraq and Afghanistan. ${ }^{3}$ Therefore, the number of cranial defects has risen dramatically, forcing new ideas and procedures to be used.

Current cranial vault reconstruction nearly exclusively uses alloplast implants and applies a staged approach to complex repairs. ${ }^{15}$ Autograft implants have been largely abandoned due to high infection and absorption rates. Also, frequent bihemispheric injury limits the use of contralateral cranial bone harvest. Injuries that include associated orbitomaxillofacial trauma require delayed cranial reconstruction. Orbital bar disruption is repaired with autologous bone grafting, and separation of the facial sinuses by pericranial flap, free flap, or dermal fat graft is performed if necessary. At a later time, a custom plate is implanted over the cranial defect. ${ }^{16,28}$ More simple cranial defects can be repaired in a single-stage procedure.

Risk factors for cranioplasty failure have been documented in this military population. Failed reconstructions were associated with close proximity to the facial sinuses, frontoorbital bone loss, and repair of the orbit with allograft. A large endocranial dead space (more than $2 \mathrm{~cm}$ from the dura mater to the undersurface of the skull) also is a risk factor for failure. ${ }^{15,16}$ These complex and at-risk reconstructions have further forced surgeons to evaluate and study their current techniques and outcomes to create more effective and safe surgical procedures. Future investigations should include regenerative cranial defect solutions including progenitor cell therapy, allograft bone scaffold reconstruction, protected bone regeneration, and augmentation of bone regeneration by using bone morphogenetic proteins.

\section{Return to Duty}

With more soldiers surviving their initial injury and more successful cranioplasties being performed, the thought of returning to duty after a cranioplasty is not far-fetched. Even in WWII, Major Woodhall realized this concern: "Thus, in the practice of military neurosurgery, it is imperative to repair all skull defects over three centimeters in a diameter if a return to duty status is desired." 31 Few studies have investigated this specific question. Lemcke et al. ${ }^{18}$ evaluated the effect of gunshots on different materials and thicknesses of cranioplasty grafts. It was discovered that polyetheretherketone material did not offer any resistance to the bullet. However, thicker titanium plates provided some protection from the ballistic action. Obviously, more trials are needed in this area before specific recommendations on the safety of return to combat duty can be made. Currently, a multidisciplinary approach to rehabilitation is recommended, including posttraumatic cranial injury counseling, skill restoration using simulation techniques in Centers for the Intrepid, and extensive retraining with an emphasis on occupational therapy.

\section{Conclusions}

There is evidence that cranioplasty has been practiced by surgeons for thousands of years. Beginning as the simple placement of a piece of foreign material over a cranial defect, the technique of cranioplasty has evolved into what is sometimes a multistage, orbitocranial complex reconstruction. Through the centuries, conflict, battle, and war have resulted in a nearly continuous line of head injury and subsequent cranial defects. It is through this pipeline that the art and science of cranial reconstruction has been developed and advanced. As in the past, what is learned through military cranioplasty can be applied to civilian trauma and is able to benefit a wider number of patients.

\section{Disclosure}

The authors report no conflict of interest concerning the materials or methods used in this study or the findings specified in this paper.

Author contributions to the study and manuscript preparation include the following. Conception and design: all authors. Acquisition of data: Bonfield. Analysis and interpretation of data: Bonfield. Drafting the article: all authors. Critically revising the article: all authors. Reviewed submitted version of manuscript: all authors. Approved the final version of the manuscript on behalf of all authors: Bonfield.

\section{References}

1. Aciduman A, Belen D: The earliest document regarding the history of cranioplasty from the Ottoman era. Surg Neurol 68:349-353, 2007

2. Asenjo A: Trephining among the American peoples: Inca trephination, in Asenjo A (ed): Neurosurgical Techniques. Springfield, IL: Charles C Thomas, 1963, pp 20-26

3. Bell RS, Ecker RD, Severson MA III, Wanebo JE, Crandall $\mathrm{B}$, Armonda RA: The evolution of the treatment of traumatic cerebrovascular injury during wartime. A review. Neurosurg Focus 28(5):E5, 2010

4. Blackburn TP, Edge DA, Williams AR, Adams CB: Head protection in England before the first World War. Neurosurgery 47:1261-1286, 2000

5. Chisolm JJ: A Manual of Military Surgery for the Use of Surgeons in the Confederate States Army. Columbia, SC: Evans \& Cogswell, 1864 (Reprint, Dayton, OH: Morningside House, 1983)

6. Courville CB: Cranioplasty in prehistoric times. Bull Los Angel Neuro Soc 24:1-8, 1959

7. Cushing H: Notes on penetrating wounds of the brain. Br Med J 1:221-226, 1918

8. Cushing H: Surgery of the head, in Keen WW (ed): Surgery, Its Principles and Practice. Philadelphia: WB Saunders, 1908, Vol 3, pp 17-276

9. Daland J: Depressed fracture and trephining of the skull by the Incas of Peru. Ann Med Hist 7:550-558, 1935

10. Fulcher OH: Tantalum as a metallic implant to repair cranial defects. JAMA 121:931-933, 1943 


\section{M. Bonfield, A. R. Kumar, and P. C. Gerszten}

11. Gurdjian ES: The treatment of penetrating wounds of the brain sustained in warfare. A historical review. J Neurosurg 40:157-167, 1974

12. Haeseker B: Mr. Job van Meekeren (1611-1666) and surgery of the hand. Plast Reconstr Surg 82:539-546, 1988

13. Horrax G: Neurosurgery: An Historical Sketch. Springfield, IL: Charles C Thomas, 1973, pp 5-12

14. Horsley V: Brain surgery in the Stone Age. Br Med J 1:582587,1887

15. Kumar AR, Bradley JP, Harshbarger R, Stevens F, Bell R, Moores L, et al: Warfare-related craniectomy defect reconstruction: early success using custom alloplast implants. Plast Reconstr Surg 127:1279-1287, 2011

16. Kumar AR, Tantawi D, Armonda R, Valerio I: Advanced cranial reconstruction using intracranial free flaps and cranial bone grafts: an algorithmic approach developed from the modern battlefield. Plast Reconstr Surg 130:1101-1109, 2012

17. Lastres JB, Cabieses F: La Trepanacion del Craneo en el antiguo Peru. Lima, Peru: Universidad Nacional del Cuzco, 1960

18. Lemcke J, Löser R, Telm A, Meier U: Ballistics for neurosurgeons: effects of firearms of customized cranioplasty implants. Surg Neurol Int 4:46, 2013

19. MacCurdy GC: Human skeletal remains from the highlands of Peru. Am J Phys Anthropol 6:217-267, 1923

20. McLeod GHB: Notes on the Surgery of the War in the Crimea, with Remarks on the Treatment of Gunshot Wounds. Philadelphia: Lippincott, 1862

21. Meekeren JJ: Observationes Medico-Chirugicae. Amsterdam: Ex Officina Henrici \& Vidnae Theodori Boom, 1682

22. Mitchell AB: Repair of injuries to the skull by perforated plates. Br J Surg 5:40-41, 1917

23. Pudenz RH: The repair of cranial defects with tantalum: an experimental study. JAMA 121:478-481, 1943

24. Ragel BT, Klimo P Jr, Martin JE, Teff RJ, Bakken HE, Armonda RA: Wartime decompressive craniectomy: technique and lessons learned. Neurosurg Focus 28(5):E2, 2010
25. Rifkinson-Mann S: Cranial surgery in ancient Peru. Neurosurgery 23:411-416, 1988

26. Sanan A, Haines SJ: Repairing holes in the head: a history of cranioplasty. Neurosurgery 40:588-603, 1997

27. Shoja MM, Agutter PS, Loukas M, Shokouhi G, Khalili M, Farhoudi M, et al: Cranioplasty in medieval Persia and the potential spread of this knowledge to Europe. Childs Nerv Syst 28:1993-1996, 2012

28. Stephens FL, Mossop CM, Bell RS, Tigno T Jr, Rosner MK, Kumar A, et al: Cranioplasty complications following wartime decompressive craniectomy. Neurosurg Focus 28(5):E3, 2010

29. United States Surgeon General's Office: Medical and Surgical History of the War of the Rebellion: (1861-1865). Washington, DC: US Government Printing Office, Vol 1, 1883

30. Webster JE, Schneider RC, Lofstrom JE: Observations on early type of brain abscess following penetrating wounds of the brain. J Neurosurg 3:7-14, 1946

31. Woodhall B, Spurling RG: Tantalum cranioplasty for war wounds of the skull. Ann Surg 121:649-668, 1945

32. Woolf JI, Walker AE: Cranioplasty: collective review. Int Abstr Surg 81:1-23, 1945

33. Zellem RT: Wounded by bayonet, ball, and bacteria: medicine and neurosurgery in the American Civil War. Neurosurgery 17:850-860, 1985

Manuscript submitted November 5, 2013.

Accepted January 20, 2014.

Please include this information when citing this paper: DOI: 10.3171/2014.1.FOCUS13504.

Address correspondence to: Christopher M. Bonfield, M.D., 200 Lothrop St., Ste. B400, Pittsburgh, PA 15213. email: bonfieldcm@ upmc.edu. 